\title{
The environmental resource curse hypothesis:
} the forest case

\author{
Olivier DAMETTE \\ Philippe DELACOTE
}

Septembre 2009

Document de travail

$n^{\circ}$ 2009-04 


\title{
The environmental resource curse hypothesis: the forest case ${ }^{*}$
}

\author{
Olivier DAMETTE ${ }^{1,2}$ \\ Philippe DELACOTE ${ }^{3,4}$
}

Septembre 2009

Document de travail du LEF n ${ }^{\circ}$ 2009-04

\begin{abstract}
Résumé
L'hypothèse de malédiction environnemental des ressources: le cas des forêts

L'hypothèse de malédiction des ressources repose sur la tendance des pays riches en ressource à avoir une croissance inférieure aux pays moins dotés. En se focalisant sur la thématique forestière, cet article étend l'hypothèse de malédiction des ressources à la dégradation environnementale: quels sont les effets des dotations et de l'exploitation forestières sur la déforestation?

Nos résultats empiriques montrent que les pays avec de larges couverts forestiers et des secteurs forestiers importants on tendance à connaître plus de déforestation que les autres, ce qui supporte l'hypothèse d'un malédiction environnementale des ressources. A l'inverse, les pays qui s'appuient davantage sur la certification de leur forêt connaissent de moindre niveaux de déforestation.

Mots clés : malédiction des ressources, forêt tropicale, déforestation.
\end{abstract}

\begin{abstract}
The resource curse hypothesis relies on the resource-rich countries tendency to grow slower than resource-poor countries. Focusing on forest issues, this paper extends the resource curse hypothesis to environmental degradation: how do forest endowment and forest harvesting affect deforestation?

Our empirical results show that countries with important forest cover and forestry sectors seem to deforest more than others, which supports the hypothesis of an environmental resource curse. Moreover, countries implied in important timber certification processes have lower deforestation levels.
\end{abstract}

Key words : resource curse, tropical forest, deforestation.

Classification JEL : C21, O13, Q33.

\footnotetext{
* Acknowledgement: this paper has been presented at the CEA annual conférence (Toronto, Canada, May 2009). We thank the participants for useful comments.

${ }^{1}$ Université Paris 12

${ }^{2}$ Beta, BETA-CNRS, Université de Nancy, Faculté de Droit Economie et Gestion, F-54000 Nancy, France

${ }^{3}$ INRA, UMR 356 Economie Forestière, F-54000 Nancy, France

Corresponding author: philippe.delacote@eui.eu

${ }^{4}$ AgroParisTech, Engref, Laboratoire d'Economie Forestière, F-54000
} 


\section{Introduction}

A well documented paradox in the economic development literature is the tendency of resource-rich countries to grow slower than countries with less natural resources. Researchers (Leite et al., 2002; Mehlun et al., 2006a, 2006b; Papyrakis et al., 2004; Sachs and Warner, 1997, 1999) usually focus on growth to describe a resource curse. Bulte et al. (2005) find evidence of the resource curse for several human development indicators. However, important resource endowments may also have an impact on the environment. Important dotations may be related to poor institutions and policy making. Poorly developed institutions may lead in turn to unsustainable environmental management. Among different environmental concerns, deforestation is interesting to analyze. Indeed forests constitute both an environmental indicator and an exploitable natural resource. Thus we investigate for an environmental resource curse for deforestation: do forest-rich countries tend to deforest more than others?

We test for an environmental resource curse, using two different forest indicators: a forest endowment indicator and a forest harvesting indicator. Controlling for corruption and institutional development, we find some evidence of an environmental resource curse for both variables. Conversely, countries with large certified timber assessment tend to deforest less than others.

Section 2 surveys the institutional explanation of the resource curse, and mentions the potential for an environmental resource curse. Section 3 investigates empirically the existence of a resource curse for deforestation, and section 4 concludes.

\section{Institutions, the resource curse and deforestation}

Among the potential transmission channels of the resource curse identified in the literature (Papyrakis and Gerlagh, 2004; Sachs and Warner, 1999), institutional quality and rentseeking is potentially the most important and relevant cause.

Natural resources are usually considered as easily appropriable, so that there are large incentives for rent-seeking activities, such as bribes or lobbying. This "voracity effect" (Mehlun et al., 2006) constitutes a diversion of labor and capital from more productive activities. As an extreme case, natural resource appropriation may be a source of conflicts or political 
violence. Most papers conclude that institutional background is an important vector of the resource curse: administrations with low levels of corruption reduce the incentive for rentseeking activities and thus decrease the importance of this transmission channel. Therefore, countries with well-developed institutions could even turn a curse into a blessing (Mehlun et al., 2006; Arezki and Van der Ploeg, 2007).

However poor institutions may be a consequence of resource wealth (Leite and Weidmann, 2002). Indeed natural resources represent for governments "easy money" that may lead to sloth in the development of institutional quality and economic policies. Then low quality institutions lead to bad economic management, poor decision making, bad or low investment decisions, unsustainable management of the resource and thus jeopardize long term growth. Overall, large resource endowments may influence institutional quality (Hall and Jone, 1999), which in turn reduces growth and threatens long-term development. Overall, corruption and rent-seeking activities seem to be key transmission factors of the potentially negative influence that natural resource dotations may have on growth and development.

Deforestation and the environmental resource curse hypothesis: Those two factors also have a strong influence on environmental quality ${ }^{1}$ and especially deforestation. Indeed, corruption and rent-seeking activities are frequently cited factors of forest over-exploitation in developing countries (Amacher, 2006; Delacote, 2008). More generally, poor institutional quality is likely to induce poor policy making, which generates unsustainable forest management. Overall, many empirical analysis find that better institutions reduce deforestation (Arcand et al., 2008; Culas, 2006; Nguyen Van and Azomahou, 2006). It is therefore crucial to control for institutional quality when testing for an environmental resource curse.

We test two kinds of environmental resource curse. First, we consider forest dotations. Deforestation is perceived cheaper for a country with large forest dotations. The implicit idea is that the net benefit (or cost) of deforesting is decreasing (increasing) in forest scarcity ${ }^{2}$. Net benefit of deforestation contents the benefit of agricultural expansion and the environmental costs of reducing the forest cover. Thus we expect a positive impact of forest dotations on deforestation. Second, we consider forest harvesting. Deforestation is related to changes in

\footnotetext{
${ }^{1}$ see Lopez and Mitra (2000).

${ }^{2}$ Rudy et al. (2005) and Ewers (2006) give some evidence of this forest transition hypothesis.
} 
the land use, while sustainable forest harvesting implies no switch in the land use. Thus, if forest harvesting is sustainable, it should have no impact on deforestation. Conversely, if forest harvesting is not sustainable, it would tend to increase deforestation. Finally, we consider certified (FSC) forest areas, to control for sustainable forest harvesting. We expect here a negative link between FSC forest areas and deforestation.

\section{Is there a resource curse for deforestation?}

\subsection{Data and regressions}

We carry out an econometric analysis using cross-country regression. We regress our deforestation proxy (Deforestation) on a vector of natural resource endowments (Resource) and a vector of other potential explanatory variables $(H)$ :

$$
\text { Deforestation }^{i}=\beta_{0}+\beta_{1} \text { Resource }^{i}+\beta_{2} H_{j}^{i}+u^{i}
$$

Subscript $i$ refers to the country and $j$ the explanatory variable. Our deforestation indicator is the forest cover change for the period 1990-2005:

$$
\text { Deforestation }^{i} \equiv \frac{\text { ForestCover }_{90}^{i}-\text { ForestCover }_{05}^{i}}{\text { ForestCover }_{90}^{i}}
$$

We test for two types of environmental resource curse. First, the impact of forest dotations is estimated. Our first control variable is a relative forest endowment indicator i.e. the proportion of land area covered by forests (Forest Cover; FAO; 1990). Indeed, as mentioned earlier, the perceived value of standing forests is likely to be smaller for countries with large forest endowment. Thus, a country with an important forest cover is likely to deforest more than a country with small forest cover.

Second, we consider the impact of forest harvesting, using industrial roundwood production divided by GDP, which is a proxy for the share of GDP provided by the forestry sector (Forest Sector; FAO; 1985). This proxy is somehow tricky, but the FAO (Food Agricultural Organization) only provides roundwood production data in volumes. As discussed before, sustainable forest harvesting should have no or small impact on the forest cover, while un- 
sustainable forest exploitation should increase deforestation. Indeed, the FAO definition of the forest cover is: Land spanning more than 0.5 hectares with trees higher than 5 meters and a canopy cover of more than 10 percent. Forest exploitation leads to deforestation only if the cover decreases to less than $10 \%$. An environmental resource curse would therefore come from unsustainable forest exploitation.

Our first control variable concerns sustainable harvest. Indeed, we consider the size of FSC certified forest area (Certified; UNEP; 2005). A country relaying on sustainable harvesting is likely to experience lower levels of deforestation. The second type of control variables approximates institutional quality. We use the IRIS corruption index (Corruption; IRIS; 1982). We expect a negative impact of corruption (positive impact of the index) on the forest cover: rent-seeking behaviors and poor institutions to appropriate forest resources are likely to increase deforestation. Third, we consider the annual growth rate of GDP as a potential explanatory variable (Growth; Penn World Tables; 1970-90) ${ }^{3}$. Finally, an indirect resource curse is estimated using the share of primary products exports in National GNP (PrimaryExports; World Data; 1970), which is the usual indicator of resource dotations in the resource curse literature. An indirect environmental resource curse would come from road creation and bad environmental management due to poor institutions.

In line with Papyrakis and Gerlagh (2004), we estimate the model of equation (1) by using Ordinary Least Squares (OLS) estimator and by increasing gradually the set of variables $H$ to evaluate our theoretical background. Nevertheless, we need to control for some econometric concerns. In line with the "'GDP convergence"' literature, we can indeed expect some endogeneity problems facing reverse causality between the deforestation rate and two regressors: Forest Cover and Forest Sector. At first, endogeneity is controlled through the Hausman test (1978). Because the residuals are not significant at 10\%, there is no evidence of endogeneity (in sense of simultaneity) in our regressions. However, those results should be interpreted cautiously because the inability of the Hausman test to identify endogeneity is likely to reflect the small sample size ( $N=40$ in this case). Thus we also estimate equation (1) excluding Certification, in order to increase our sample size $(N=70)$. At second, we choose variables refereing either to the beginning of the considered period (1990) or before

\footnotetext{
${ }^{3}$ We voluntarily ignore the Environmental Kuznets Curve hypothesis here, as it is largely covered in the literature (Arcand et al., 2008; Culas, 2006).
} 
that period (we use Forest Cover in 1985). In addition, we control for heteroskedasticity concerns, normalizing roundwood production and certified forest area to GDP, and performing regressions using White-Heteroskedasticity-Consistent Standard Errors and Covariance. Multicolinearity is ruled out through the Variance Inflation Factor (VIF) index. Finally we test for the robustness of our regressions using some specification test like the Ramsey's RESET test (1969). Besides, the addition of other possible determinants of the deforestation (Primary Export for instance) does not change the significance of our variables of interest of our findings. Our coefficients of interest are quite stable.

\subsection{Main results and conclusion}

1) Countries with relatively important forest cover have deforested more over the considered period than countries with small forest cover. Deforestation is thus perceived cheaper for a country with large forest endowments, confirming the forest transition hypothesis.

2) We find some evidence of an environmental forest resource curse: countries relying heavily on forest harvesting have deforested more than countries with small forestry sectors. Moreover the estimated tendency is robust when controlling for corruption. This result gives the alarming insight that forest exploitation is mainly unsustainable worldwide, independently of institutional factors.

3) Deforestation appears significantly more important in countries with poorer institutions. Unsurprisingly, corruption, rent-seeking behaviors and poor political management facilitate resource appropriation, limits law enforcement and thus favors land appropriation and unsustainable forest use.

4) Countries relying on more on sustainable harvesting (through FSC certification) deforest less than the others. It thus appears that certification is quite representative of better environmental management, and could be taken into account in the context of global warming mitigation.

5) We do not find evidence of an indirect environmental resource curse. The coefficient related to natural exports is no significant at $10 \%$ and is consequently ruled out the final model. In addition, the growth significantly (at 10\%) dampens the deforestation rate. 
Table 1: Deforestation regression as in Equation (1)

\begin{tabular}{|c|c|c|}
\hline Deforestation & & \\
\hline \multirow[t]{2}{*}{ Forest Cover } & 0.35 & 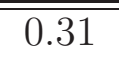 \\
\hline & (3.89) & (3.24) \\
\hline \multirow[t]{2}{*}{ Forest Sector } & 0.13 & 0.18 \\
\hline & (3.52) & (2.69) \\
\hline \multirow[t]{2}{*}{ Certified } & -0.11 & - \\
\hline & $(-2.67)$ & $(-)$ \\
\hline \multirow[t]{2}{*}{ Corruption ${ }^{\dagger}$} & -3.02 & -3.07 \\
\hline & $(-4.03)$ & $(-3.09)$ \\
\hline \multirow{2}{*}{ Growth } & -1.25 & -2.82 \\
\hline & $(-1.58)$ & $(-1.84)$ \\
\hline Adjusted $R^{2}$ & 0.50 & 0.40 \\
\hline $\mathrm{N}$ & 40 & 70 \\
\hline
\end{tabular}

t-statistics are in parentheses.

All variable are significant at $1 \%$ level of significance, except Growth (10\%).

PrimaryExports and the constant are not significant at $10 \%$ and dropped from the main model.

${ }^{\dagger}$ Corruption index: low score means high corruption

\section{References}

Amacher, G. (2006). Corruption: A challenge for economists interested in forest policy design. Journal of Forest Economics, 12:85-89.

Arcand, J., Guillaumont, P., and Guillaumont-Jeanneney, S. (2008). Deforestation and the real exchange rate. Journal of Development Economics, 86(2):242-262.

Arezki, R. and Van der Ploeg, R. (2007). Can the natural resource curse be turned into a blessing? the role of trade policies and institutions. IMF Working Papers 07/55, International Monetary Fund.

Breush, T. and Pagan, A. (1979). A simple test for heteroskedasticity and random coefficient variation. Econometrica, 48:1287-1294.

Brown, R., J., D., and J.M., E. (1975). Techniques for testing the constancy of regression relationships over time. Journal of the Royal Statistical Society, Series B, 37:149-192.

Bulte, E., Damania, R., and Deacon, R. (2005). Resource intensity, institutions and development. World Development, 33(7):1029-1044. 
Culas, R. (2006). Deforestation and the environmental kuznets curve: An institutional perspective. Ecological Economics, forthcoming.

Delacote, P. (2008). Systemic corruption, scale effects and forest harvesting. Working Paper, LEF-INRA.

Ewers, R. (2006). Interaction effects between economics development and forest cover determine deforestation rates. Global Environmental Change, 16:161-169.

Godfrey, L. and Pagan, A. (1978). Testing for multiplicative heteroskedasticity. Journal of Econometrics, 8:227-236.

Hall, R. and Jones, C. (1999). Why do some countries produce so much more output than others. Quaterly Journal of Economics, 114:83-116.

Hausman, J. (1978). Specification tests in econometrics. Econometrica, 46:1251-1272.

Leite, C. and Weidmann, J. (2002). Does mother nature corrupt? Natural resources, corruption and economic growth, pages 156-169. Governance, corruption and economic performance. Abed, G. and Gupta, S. (eds.), Washington, DC; International Monetary Found. Lopez, R. and Mitra, S. (2000). Corruption, pollution, and the kuznets environment curve. Journal of Environmental Economics and Management, 40:137-150.

Mehlun, H., Moene, K., and Torvik, R. (2006). Institutions and the resource curse. The Economic Journal, 116:1-20.

Nguyen Van, P. and Azomahou, T. (2006). Nonlinearities and heterogeneity in environmental quality: An empirical analysis of deforestation. Journal of Development Economics, 84:291-309.

Papyrakis, E. and Gerlagh, R. (2004). The resource curse hypothesis and its transmission channels. Journal of Comparative Economics, 32:181-193.

Ramsey, J. (1969). Test for specification errors in classical linear least squares regression analysis. Journal of the Royal Statistical Society, Series B, 31:350-371. 
Rudel, T., Coomes, O., Moran, E., Achard, F., Angelsen, A., Xu, J., and Lambin, E. (2005). Forest transitions: towards a global understanding of land use change. Global Environmental Change, 15:25-31.

Sachs, J. and Warner, A. (1997). Natural resource abundance and economic growth. Center for International Development and Harved Institute for International Development.

Sachs, J. and Warner, A. (1999). The big push, natural resource booms and growth. Journal of Development Economics, 59:43-76.

White, H. (1980). A heteroskedasticity-consistent covariance matrix and direct test for heteroskedasticity. Econometrica, 48:817-838. 